\title{
Long-Term Change in Characteristics of Cloud Vertical Structures Over Sumatra from Radiosonde Observations
}

\author{
Lismalini Lismalini' ${ }^{1}$, Marzuki Marzuki ${ }^{1}$, Mohammad Ali Shafii ${ }^{1}$ \\ ${ }^{1}$ Department of Physics, Faculty of Mathematics and Natural Sciences, \\ Universitas Andalas, Padang, Indonesia
}

\begin{tabular}{|c|c|}
\hline Article Info & ABSTRACT \\
\hline Article History: & \multirow{12}{*}{$\begin{array}{l}\text { Study on the vertical structure of cloud in Indonesia in terms of climate change } \\
\text { is still very limited. We investigated the long-term change in characteristics of } \\
\text { cloud vertical structures over Sumatra from three radiosonde observation } \\
\text { stations in this work. The cloud base height (CBH), cloud top height (CT), and } \\
\text { the number of cloud layers were retrieved using relative humidity (RH) profiles } \\
\text { from radiosonde observation. The height of the cloud base is determined by } \\
\text { taking the height of the layer with relative humidity (RH) value }>84 \% \text { with at } \\
\text { least a } 3 \% \text { jump in the RH from the ground level. Sumatra's most frequently } \\
\text { observed cloud layer is a one-layer cloud with an average occurrence rate of }> \\
60 \% \text {, which is slightly larger than the one-layer cloud globally. The percentage } \\
\text { of appearance values at the Padang station, Pangkal Pinang, and Medan are } \\
63.58 \% \text {, } 69.50 \% \text { and } 66.05 \% \text {. The appearance of low-level clouds also } \\
\text { dominates in Sumatra compared to other cloud types. CT and CBH increase } \\
\text { with the number of years including all seasons. This is in line with the increase } \\
\text { in temperature in Indonesia reported by previous researchers. On the other } \\
\text { hand, the clouds' thickness, especially for the cloud with one layer, varies from } \\
\text { one location to another. The thickness of clouds decreases at Padang station } \\
\text { and does not change at Pangkal Pinang and Medan stations. }\end{array}$} \\
\hline Received: January 29, 2021 & \\
\hline Revised: February 13, 2021 & \\
\hline Accepted: February 16, 2021 & \\
\hline Keywords: & \\
\hline Cloud vertical structures & \\
\hline Radiosonde & \\
\hline Climate change & \\
\hline Sumatra & \\
\hline Corresponding Author: & \\
\hline & \\
\hline Email: marzuki@sci.unand.ac.id & \\
\hline
\end{tabular}

\section{INTRODUCTION}

Clouds influence the balance of energy radiation on earth through the process of absorption and reflection of sunlight entering the earth's atmosphere (Stephens et al., 2012; Zhou et al., 2016). The amount of radiant energy absorbed and reflected depends on the cloud type (Naud et al., 2016). Low clouds tend to cool the earth, and high clouds tend to heat the surface. Thus, clouds have an impact on the radiation balance on earth, and this role depends on the distribution of clouds and vertical cloud structures such as cloud top height (CT), cloud base height $(\mathrm{CBH})$, cloud thickness, and the number of cloud layers (Li et al., 2016). Cloud characteristics, including cloud height, cloud cover and cloud morphology can change with climate change (Eastman and Warren, 2013).

Surface-based observations (Dong and Minnis, 2016) and satellites (Minnis and Harrison, 1984) are widely used to study cloud profiles, such as the CloudSat satellite and the Cloud-Aerosol Lidar and Infrared Pathfinder Satellite Observation (CALIPSO). The CloudSat and CALIPSO have provided a new picture of the vertical profile of clouds. However, CloudSat has limitations in which this instrument cannot accurately identify high (thin) clouds (Marchand et al., 2008). Furthermore, considerable uncertainty of CBH values from CloudSat and CALIPSO data has also been reported (Zhang et al., 2017). More accurate CBH values can be obtained using surface-based cloud observation data such as cloud radar, lidar (Borg et al., 2011), and ceilometer (Martucci et al., 2010). Apart from the high accuracy in measuring $\mathrm{CBH}$, this instrument has a continuous temporal coverage 
Lismalini et al: Long-Term Change in Characteristics of Cloud Vertical Structures Over Sumatra

(Sharma et al., 2016). However, observation of cloud height using a ceilometer is limited to an altitude of less than $4 \mathrm{~km}$ (Dai et al., 2016). The observation points of Lidar and Ceilometer is also are still limited in the world. The deficiencies of surface and satellite observations can be overcome using radiosondes.

A radiosonde is a set of flying balloons that are used to measure atmospheric parameters and send these observational data to receiving stations via specific radio frequencies. Radiosonde operates at a frequency of $433 \mathrm{MHz}$ or $1680 \mathrm{MHz}$ (Simanungkalit, 2018). Radiosondes can reach cloud layers to measure relative humidity, temperature, and pressure to estimate the vertical profile of the atmosphere, including clouds. Besides those parameters, radiosonde also can observe the wind speed and direction. More importantly, radiosondes can reach the atmospheric layer at an altitude of $30 \mathrm{~km}$ from the earth's surface. It is possible to retrieve CT, CBH and the number of cloud layers globally (Zhang et al., 2010).

Research on the vertical structure of clouds has been carried out in various countries worldwide with long-term use of radiosonde data (Wang and Rossow, 1995; 2000; Reddy et al., 2018). However, in Indonesia, this research is very limited. Research that has been done is limited to the spatial distribution of clouds from satellite observations (Marzuki et al., 2013; 2017). For two years, observation of the distribution of the vertical structure of clouds and aerosols using lidar Mie scattering has been carried out in Jakarta. They found the maximum value of $\mathrm{CBH}$ at an altitude of 5 $\mathrm{km}$ and have not reached the top of the cloud (Sugimoto et al., 2000). Therefore, further research was conducted on the vertical structure of the cloud. This study analyzes the characteristics of the vertical cloud structure in Sumatra as a result of climate change using radiosonde data $\sim 30$ years of observation. Radiosonde observations were carried out at three observation stations, namely Padang, Pangkal Pinang, and Medan.

\section{METHOD}

The data used in this study were radiosonde data managed by the University of Wyoming (http://weather.uwyo.edu/upperair/sounding.html). The radiosonde is launched twice per day, at 12:00 UTC and 00:00 UTC. In this study, the data of two observation periods are combined. Because we are also dealing with cloud vertical structure characteristics in terms of climate change, we have only used the Radiosonde station with the data availability of at least 30 years. Of the 15 stations in Sumatra, three stations meet this criterion. The location and specification of these stations are given in Figure 1 and Table 1, respectively. Retrieval of the vertical cloud structure from radiosonde data was carried out using brightness temperature data from the observation of Multifunctional Transport Satellites (MTSAT).

The cloud parameters were determined using the method proposed by Wang and Rossow (1995). CBH and CT are determined by taking the lowest and highest layers with relative humidity $(\mathrm{RH})>84 \%$. RH profiles $>84 \% \mathrm{RH}$ should be observed for at least four successive gate ranges with a $3 \%$ jump of RH in the basement layer. All radiosonde sounding profiles are not taken when the altitude is $<600 \mathrm{~m}$ above ground level (AGL). The difference between the base and the crest is defined as the thickness of the cloud.

After the parameters are determined, we calculate the proportion of cloud occurrences. The percentage of cloud occurrences is obtained from the number of occurrences of a cloud layer for $\sim 30$ years divided by the total cloud layer data at each observation station. Once the cloud vertical structure parameters such as $\mathrm{CBH}, \mathrm{CT}$, and the number of cloud layers were obtained, the clouds were grouped into four categories: low, middle, high, and deep convective clouds, following the method used by previous researchers (Lazarus et al., 2000; Zhang et al., 2010). Low-level clouds are defined as clouds with a thickness of $<6 \mathrm{~km}$ and $\mathrm{CBH}<2 \mathrm{~km}$. Furthermore, intermediate level clouds are assumed if $\mathrm{CBH}$ ranges from $2 \mathrm{~km}$ to $5 \mathrm{~km}$. For $\mathrm{CBH}>5 \mathrm{~km}$, clouds are defined as high-level clouds. Finally, deep convective clouds are shown $>6 \mathrm{~km}$ thick and $\mathrm{CBH}<2 \mathrm{~km}$. Clouds are also grouped based on the season period December-January-February (DJF), June-July-August (JJA), September-OctoberNovember (SON), and March-April-May (MAM) to see seasonal cloud variations. 


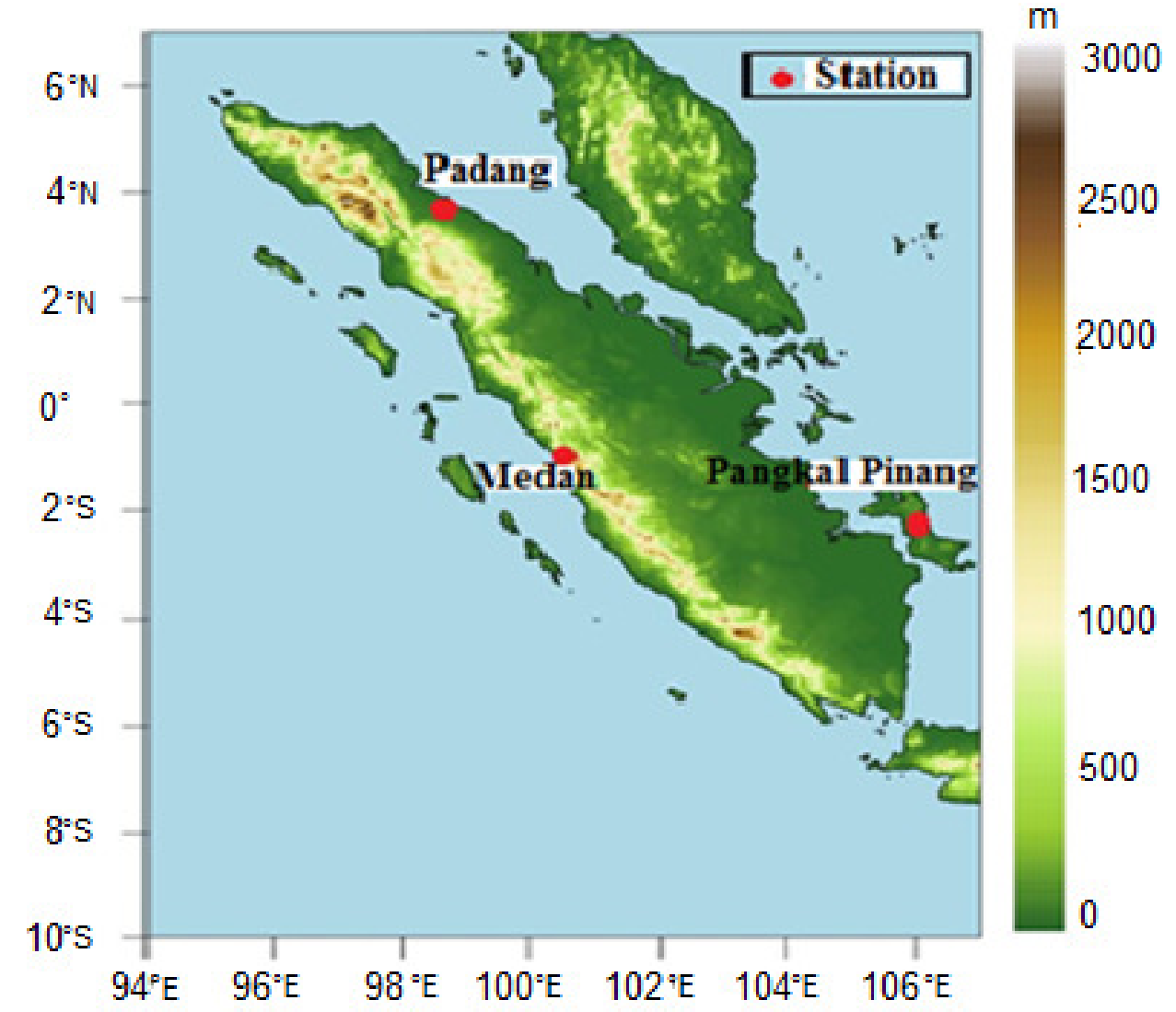

Figure.1 Location of radiosonde stations.

Table 1. Duration of radiosonde observation used in this study

\begin{tabular}{ccccccc}
\hline No & No station & Station ID & Station name & Latitude & Longitude & Observation year \\
\hline 1 & 96163 & WIMG & Padang & $0.88^{\circ} \mathrm{S}$ & $100.35^{\circ} \mathrm{W}$ & $1988-2019$ \\
2 & 96035 & WIMM & Medan & $3.57^{\circ} \mathrm{N}$ & $98.68^{\circ} \mathrm{W}$ & $1975-2019$ \\
3 & 96237 & WIKK & Pangkal Pinang & $2.16^{\circ} \mathrm{S}$ & $106.13^{\circ} \mathrm{W}$ & $1985-2019$ \\
\hline
\end{tabular}

\section{RESULTS AND DISCUSSION}

\subsection{Validation of Cloud from Radiosonde with MTSAT Data}

Figure 2 shows the clouds detected by MTSAT and radiosonde over the Padang station $\left(0,88^{\circ} \mathrm{S} 100,35^{\circ} \mathrm{E}\right)$. The range of brightness temperature for several weather conditions includes $60^{\circ} \mathrm{C}$ to $8^{\circ} \mathrm{C}$ (clear air), $8^{\circ} \mathrm{C}$ to $0^{\circ} \mathrm{C}$ (light cloudy), $0^{\circ} \mathrm{C}$ to $-28^{\circ} \mathrm{C}$ (cloudy), $-28^{\circ} \mathrm{C}$ to $-56^{\circ} \mathrm{C}$ (thick cloudy), and $-56^{\circ} \mathrm{C}$ to $-100^{\circ} \mathrm{C}$ (very thick cloudy) (Gunawan, 2016). On April 13, 2019, at 00.00 UTC, clouds over Padang were observed at temperatures of $245 \mathrm{~K}$ to $240 \mathrm{~K}\left(-28^{\circ} \mathrm{C}\right.$ to $\left.-33{ }^{\circ} \mathrm{C}\right)$ characterized by light blue contours (Figure 2a). This cloud is also observed by radiosonde. The RH value of $89 \%$ appears at an altitude of $4.2 \mathrm{~km}$, with a maximum RH value of $100 \%$ at an altitude of $5.8 \mathrm{~km}$ (11\% RH jump). This layer is observed until an altitude of $6 \mathrm{~km}$ (Figure 2b). From this comparison, it can be seen that cloud retrieval from radiosonde data can detect clouds observed by the MTSAT satellite correctly. 

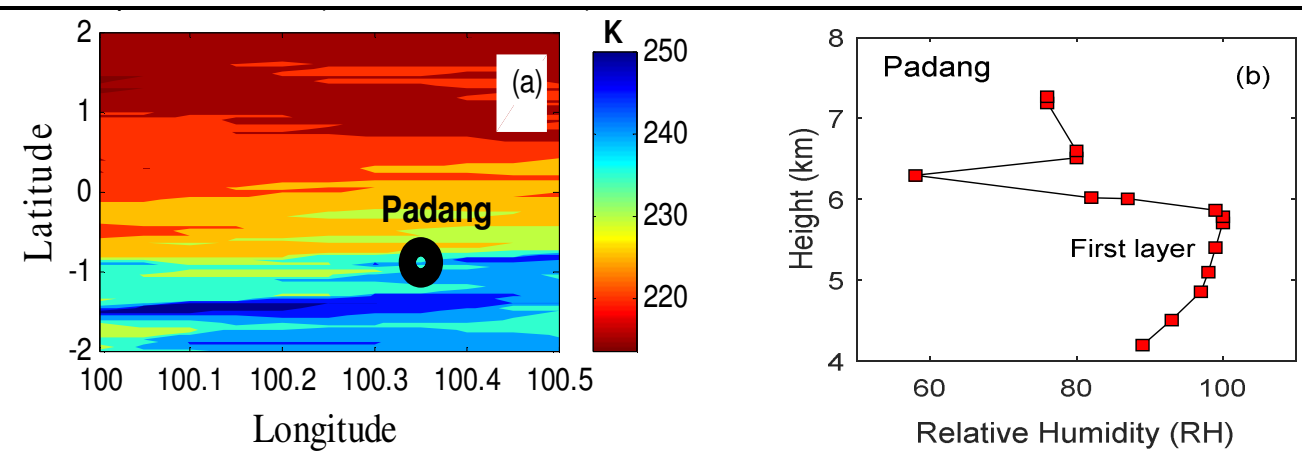

Figure 2. Cloud observed by (a) MTSAT satellites and (b) radiosonde at Padang station on April 13, 2019 at 00:00 UTC.

\subsection{Distribution of Cloud Layers and Cloud Types}

Figure $3 \mathrm{a}$ shows the distribution of the number of cloud layers from the three observation stations. One-layer, two-layer, three-layer, and four-layer clouds are the cloud layers observed in Sumatra. One-layer cloud is the cloud that appears most frequently, with an average occurrence percentage of $>60 \%$, including 63.58\% (Padang), 69.50\% (Pangkal Pinang) and 66.05\% (Medan) station. This value slightly exceeds the appearance of one layer cloud from another country.

In India, the percentage of one-layer clouds is around $40.80 \%$ (Reddy et al., 2018). Wang and Rossow (1995) and Wang et al. (2000) analyzed global radiosonde observations and found the appearance of a one-layer cloud of $44 \%$ and $58 \%$, respectively. These stations are located in areas with relatively small landmass and close to the ocean. Maritime-like clouds may be somewhat dominant at these stations. These results are consistent with previous researchers who also found high cloud incidence in oceanic regions, the proportion of one-layer clouds around 53\% (Warren et al., 1988; Lazaros et al., 2017). The percentage of occurrence of low, middle, high, and deep convective clouds is shown in Figure 3b. The clouds that occur most frequently at each station are low-level clouds. The largest percentage of low-level clouds in Sumatra is observed at Padang station (48.36\%). The observation of low-level cloud structure is in line with previous research by stating that the abundance of low level clouds over the ocean is almost three times greater than that on land (Chepfer et al., 2010; King et al., 2013). An upstream current is lower in the oceanic convective system so that the shallow clouds are more dominant in this area (Rosenfeld and Ulbrich, 2003; Marzuki et al., 2013; 2018a; 2018b).

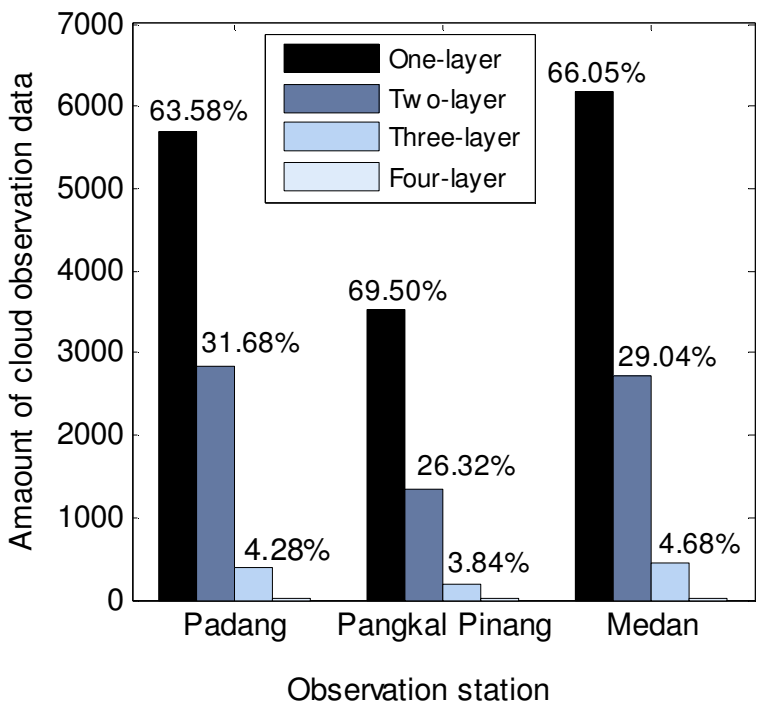

(a)

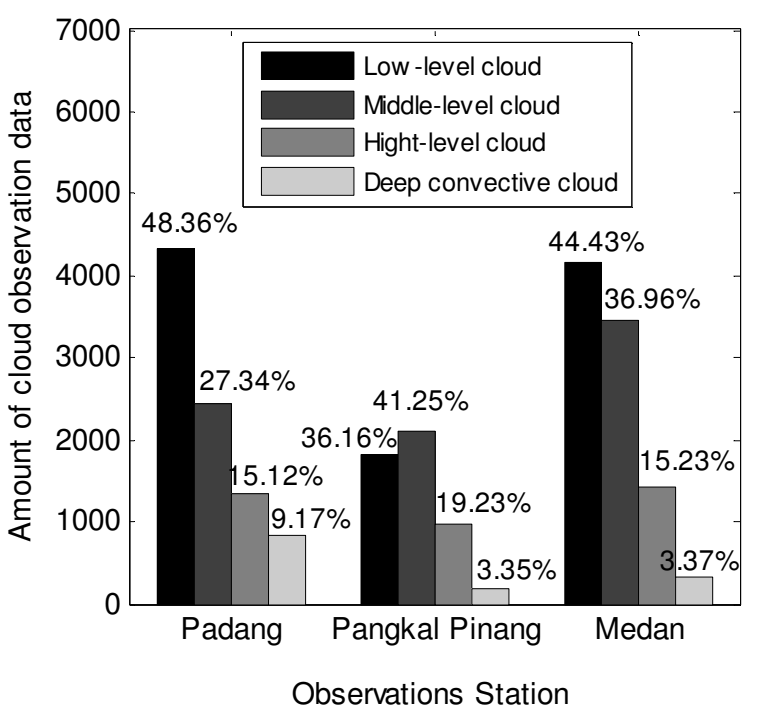

(b)

Figure 3. Distribution of observation data (a) based on the number of cloud layers (b) low-level clouds, middlelevel clouds, high-level clouds, deep convective clouds and the percentage of occurrence 


\subsection{Seasonal Variations in Cloud Vertical Structure}

Figure 4 shows the percentage of cloud layer occurrences for each observation station during DJF, JJA, MAM and SON. In general, one cloud layer is dominant in all seasons. However, the JJA period (dry season) has a larger percentage of cloud appearance than other seasons, ranging from $65 \%$ $-71 \%$. The station with the highest percentage is in Pangkal Pinang, with a value of $71.02 \%$. This period coincides with monsoon rainfall patterns, especially the dry southeast monsoon (Aldian and Susanto, 2003). Thus, although many clouds are observed at the stations during JJA, it does not produce heavy rain as they are mostly low level clouds (Lismalini et al., 2020b). During the DJF season, the percentage of cloud layer appearance was relatively large, with the stations of Padang 63.48\%, Pangkal Pinang 68.78\% and Medan 70.24\%. For the MAM and SON period, the highest percentage was also found at Pangkal Pinang station with values of $69.55 \%$ and $68.94 \%$. A high percentage of two-layer clouds are observed for all stations.

The four cloud types classified based on CBH and the cloud layer's thickness is shown in Figure 5. Low-level clouds are more dominant in appearance than other cloud types in all seasons (Figure 5a). However, of the four seasons, the JJA season (dry season) has a more dominant percentage. The minimum appearance of low-level clouds $(36.16 \%)$ occurred at Pangkal Pinang station (Figure 3b). It is consistent with low rainfall throughout the year (Marzuki et al., 2021). The deep convective cloud's appearance is relatively smaller than other clouds, i.e., about $11 \%$ (Figure 5d). However, these clouds contribute more to produce high rainfall. Therefore, the deep convective cloud's seasonal variation is more robust than other clouds, which is in line with the rainy season's occurrence (Lismalini et al., 2020b). The occurrence of deep convective clouds at Padang station is $10.09 \%$ during DJF.
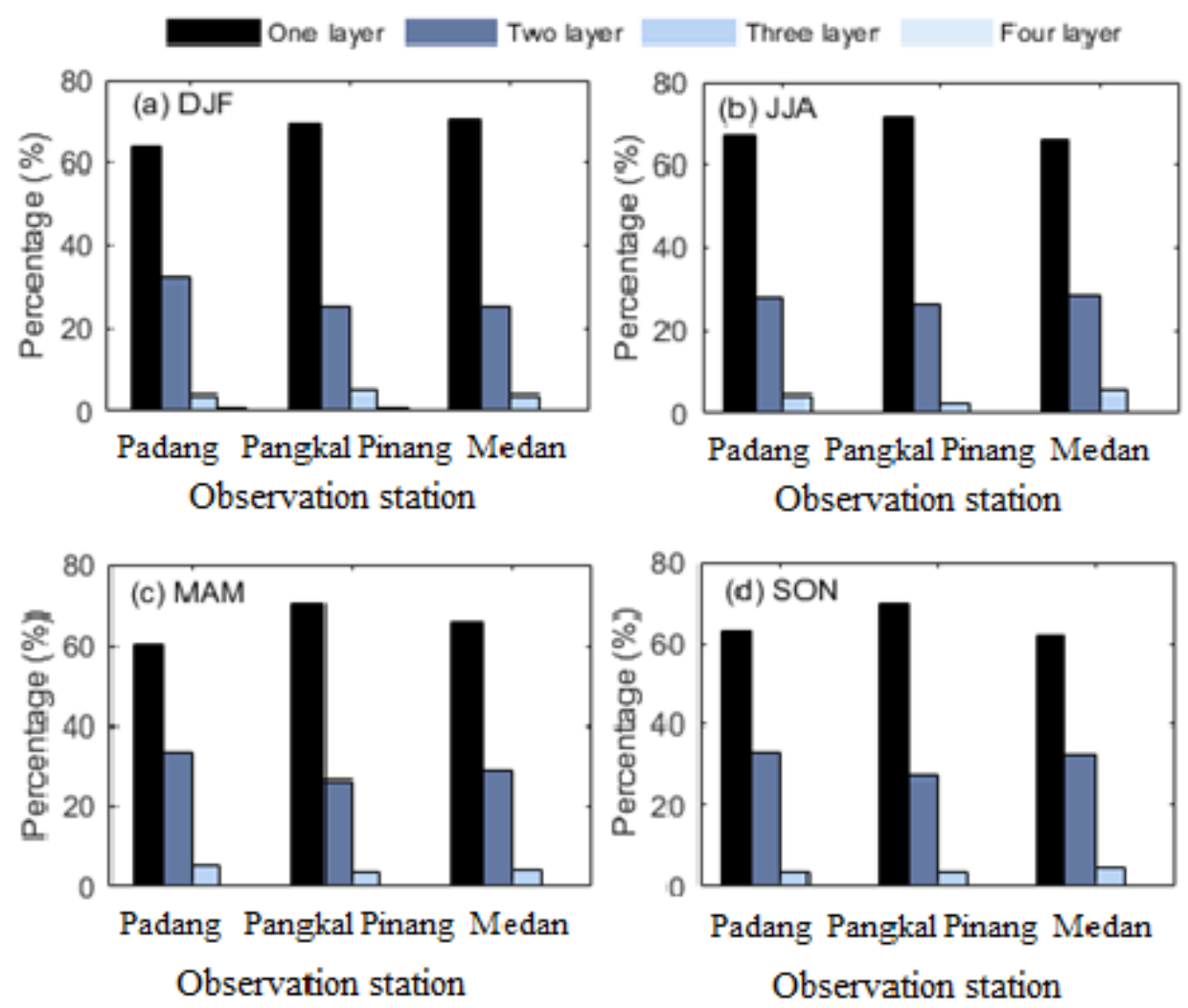

Figure 4. Occurrence Percentage of one- layer, two-layer, three-layer and four-layer clouds during (a) DJF, (b) JJA, (c) MAM, and (d) SON 


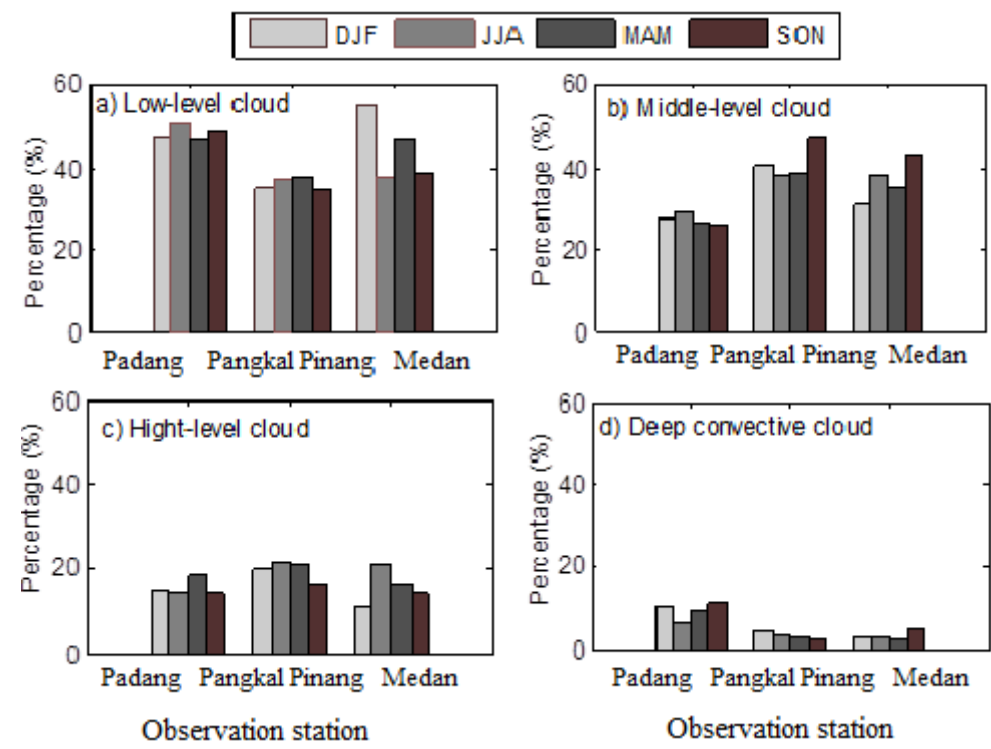

Figure. 5 Occurrence percentage of (a) low-level cloud, (b) middle-level cloud, (c) high-level cloud and (d) deep convective cloud for each season.

\subsection{Long-Term Change in Cloud Parameters}

The long-term changes of the one-layer cloud and the two-layer cloud at the Padang station are shown in Figure 6 and Figure 7. CT and CBH have increased over the past 30 years in each cloud layer. The highest increase occurred in one-layer clouds with a value of $0.04 \mathrm{~km} /$ year (Figure $6 \mathrm{a}$ and Figure $6 b)$, with the highest correlation coefficient in CBH $\left(\mathrm{R}^{2}=0.25\right)$. This study's result is consistent with Chernykh et al. (2001) who reported an increase in CT globally, including the Asian continent. However, in contrast to the cloud thickness trend at Padang station, there was a relatively small decrease in each cloud layer. Figure 8 and Figure 9 show the observed trend of cloud parameters at Pangkal Pinang station. Cloud parameters have increased in each cloud layer (CT, CBH and cloud thickness). Except for cloud layer thickness for single-layer clouds has not changed for $\sim 30$ years. The value of the increase is about $0.05 \mathrm{~km} /$ year. The increase in CT and CBH also occurred at Medan stations. The value of the increase is smaller than the Padang and Pangkal Pinang stations. The increase in CT and CBH was about $0.02 \mathrm{~km} /$ year and $0.01 \mathrm{~km} /$ year, respectively (Figure 10a and Figure 10b). The same conditions are seen in the two-layer cloud. However, the cloud layer thickness trend did not experience, as seen in Figure 11c and Figure 11f.

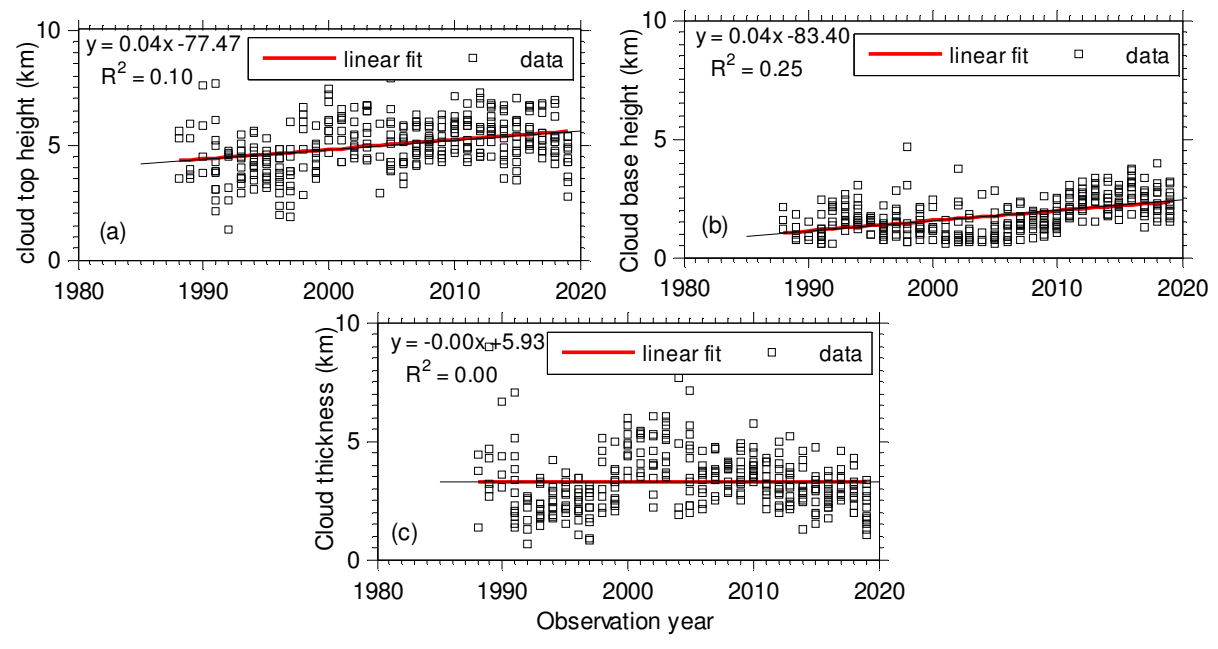

Figure 6. Time series of cloud top height (a), cloud base height (b) and cloud thickness (c) for one-layer cloud at Padang station 

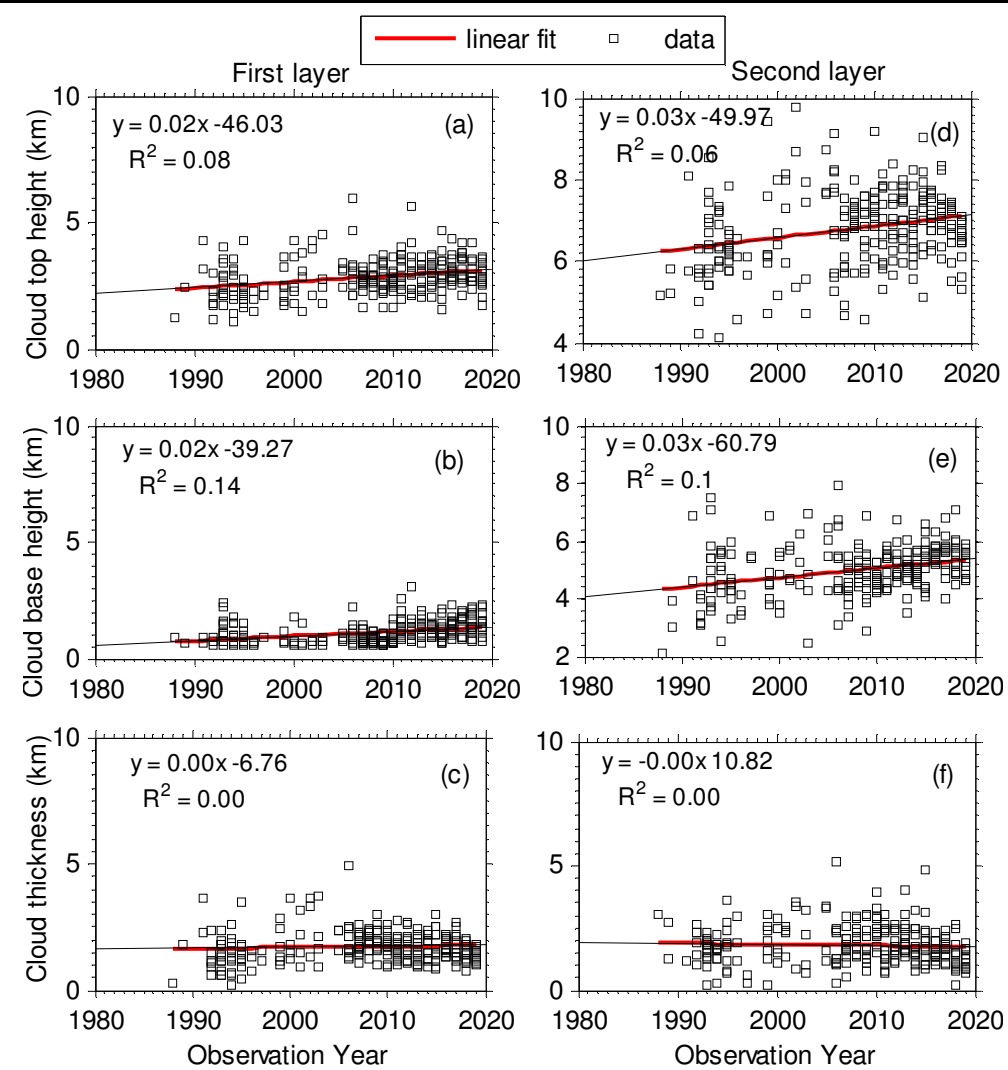

Figure 7. Time series of cloud top height ( $a$ and d), cloud base height (b and e) and cloud thickness (c and f) for two layer clouds at Padang station

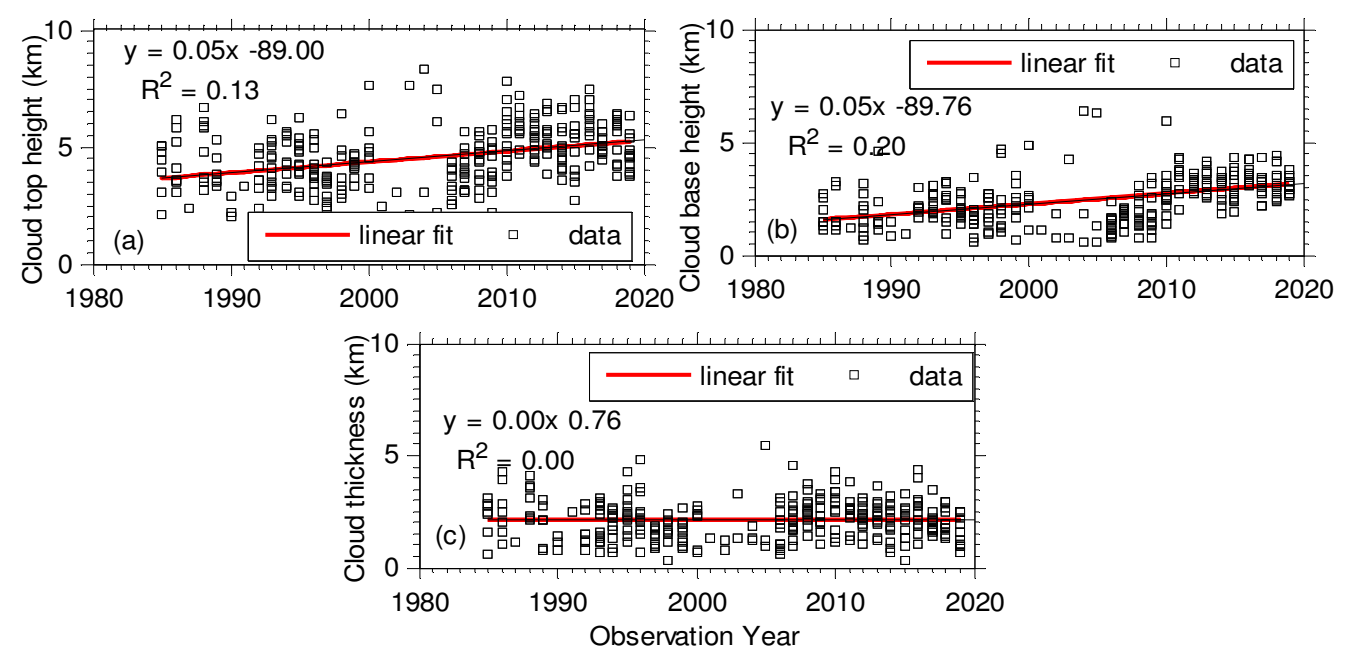

Figure 8. Time series of cloud top height (a), cloud base height (b) and cloud thickness (c) for one-layer cloud at Pangkal Pinang station

In general the $\mathrm{CT}$ and $\mathrm{CBH}$ have increased over the last 30 years from the three observation stations in Sumatra. These results are consistent with previous studies (Chernykh et al., 2001) and in accordance with the results reported by Lismalini et al. (2020a) regarding increased CT and CBH. The increase in the cloud height parameter is related to the surface temperature. Increasing earth's surface temperature will increase the height of the clouds because the convection process is closely related to temperature. The increase in surface temperature in Indonesia has been reported by several previous researchers (Susandi, 2004). The trend in cloud thickness varies for the three stations. However, if it is seen from the number of cloud layers at each station, it can be seen that the increasing number of cloud layers and the value of the cloud thickness will decrease. 


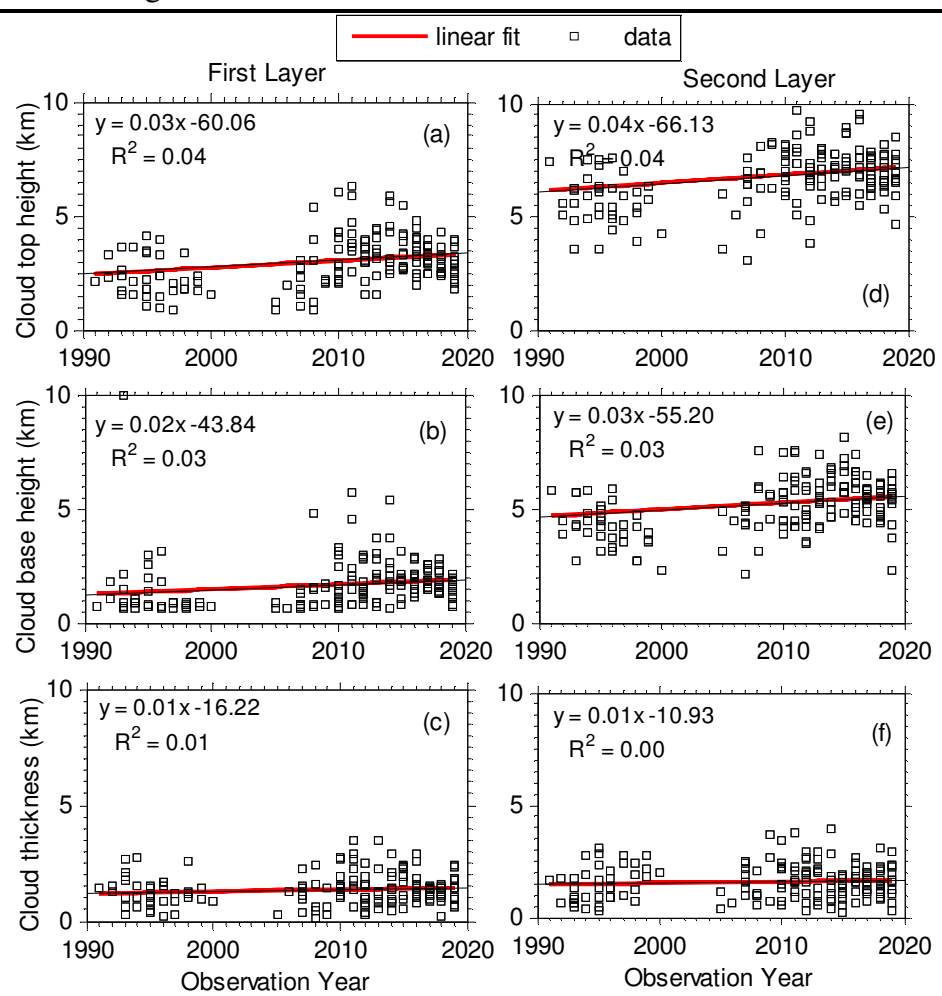

Figure 9. Time series of cloud top height (a and d), cloud base height (b and e) and cloud thickness (c and f) for two-layer clouds at Pangkal Pinang station
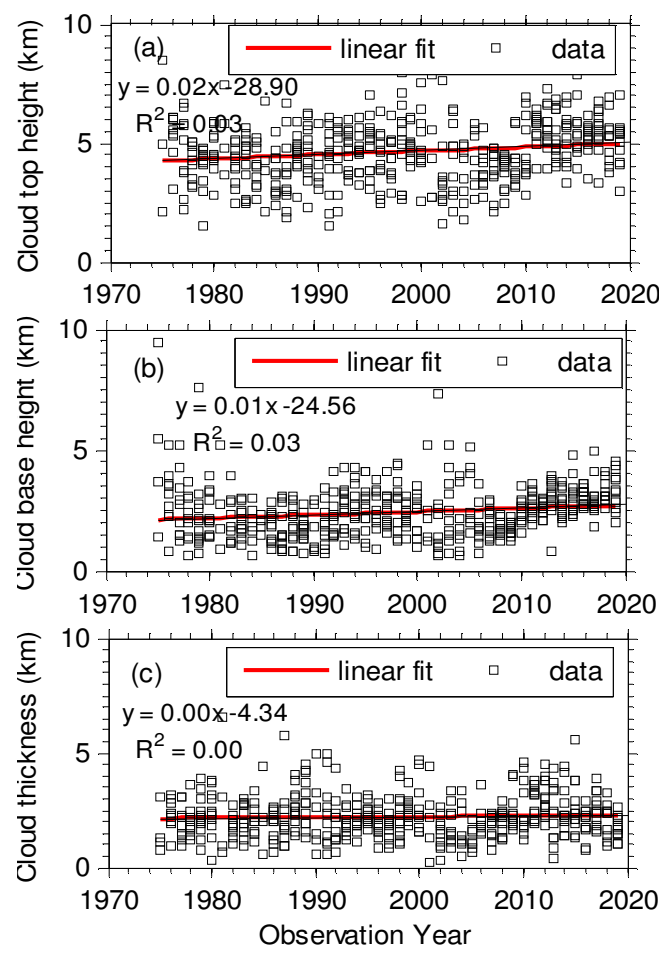

Figure 10. Time series of cloud top height (a), cloud base height (b) and cloud thickness (c) for one- layer cloud at Medan station 

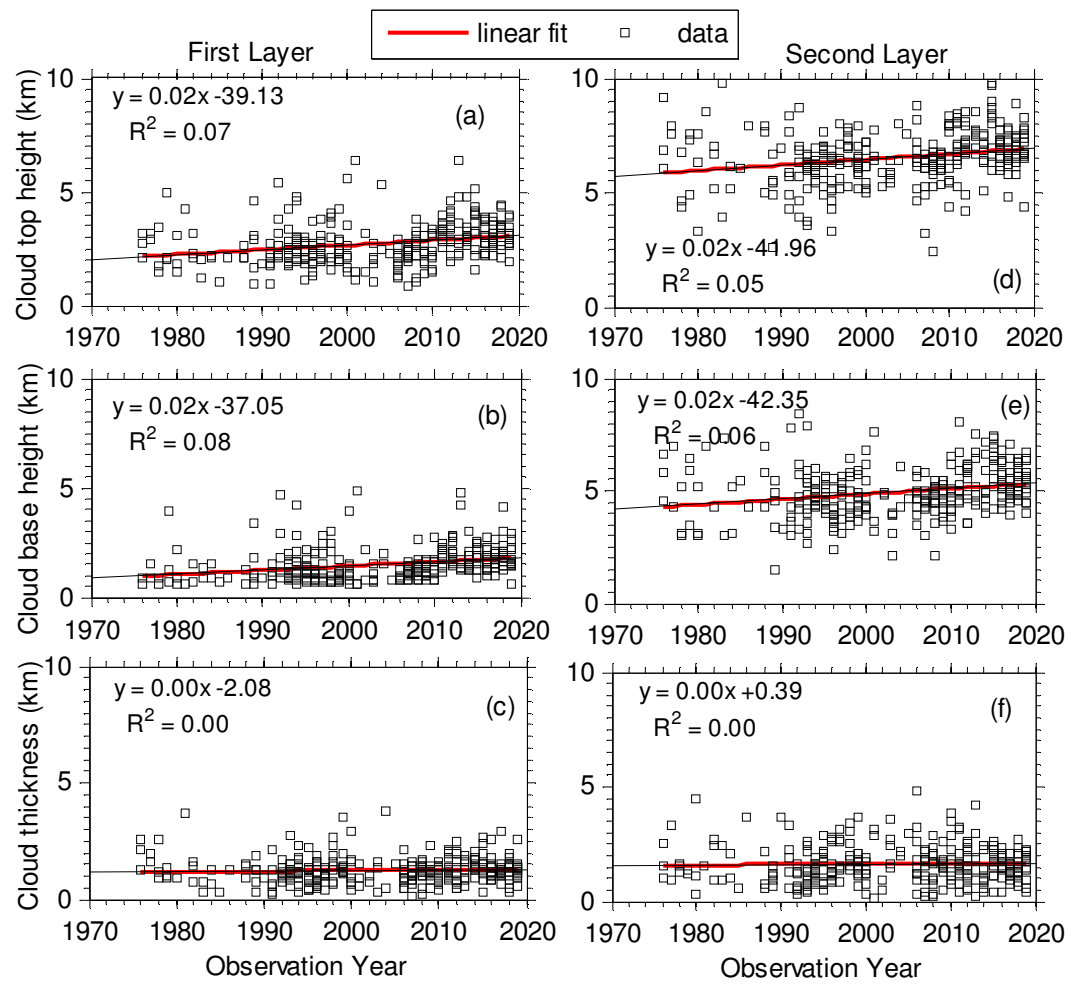

Figure 11. Time series of cloud top height (a and d), cloud base height ( $b$ and e) and cloud thickness ( $c$ and f) for two-layer clouds at Medan station

The time series of long-term changes in cloud parameters in a one-layer cloud during the DJF, JJA, MAM and SON seasons in Sumatra is shown in Figure 12. There has generally been an increase in $\mathrm{CT}$ and $\mathrm{CBH}$ across all seasons over the past 30 years. The increase in CT and $\mathrm{CBH}$ was relatively small with a low correlation coefficient, as shown in Table 1.The Largest increase was at Padang stations around $0.05 \mathrm{~km} /$ year with the highest correlation coefficient $\left(R^{2}=0.03\right)$ during the DJF season (Table 2). However, it differs from the trend of cloud layer thickness in each season. During the JJA and MAM seasons, there was a decrease in thickness at Padang stations. This can be seen from the linear regression values in Table 3 and Table 4. During the JJA and SON seasons there was also a decrease in thickness at the Pangkal Pinang station, this is shown in Table 3 and Table 5.

Table 2. Linear regression equation of one-layer cloud for DJF period

\begin{tabular}{llll}
\hline Station name & Cloud top height & Cloud base height & Cloud thickness \\
\hline Padang & $y=0.05 x 103.28$ & $y=0.05 x-91.48$ & $y=0.01 x-11.80$ \\
\hline \multirow{3}{*}{ Pangkal Pinang } & $R^{2}=0.19$ & $R^{2}=0.33$ & $R^{2}=0.02$ \\
& $y=0.06 x-118.92$ & $y=0.05 x-98.75$ & $y=0.01 x-20.18$ \\
Medan & $R^{2}=0.20$ & $R^{2}=0.28$ & $R^{2}=0.02$ \\
& $y=0.01 x-19.32$ & $y=0.01 x-24.50$ & $y=-0.00 x 5.18$ \\
& $R^{2}=0.01$ & $R^{2}=0.03$ & $R^{2}=0.00$
\end{tabular}

Table 3. Linear regression equation of one-layer cloud for JJA period

\begin{tabular}{llll}
\hline Station name & Cloud top height & Cloud base height & Cloud thickness \\
\hline Padang & $y=0.03 x-45.77$ & $\mathrm{y}=0.04 x-80.30$ & $y=-0.01 \times 34.53$ \\
& $R^{2}=0.03$ & $R^{2}=0.19$ & $R^{2}=0.01$ \\
Pangkal Pinang & $y=0.03 x-46.95$ & $\mathrm{y}=0.04 x-72.53$ & $y=-0.01 \times 25.57$ \\
& $R^{2}=0.06$ & $R^{2}=0.13$ & $R^{2}=0.02$ \\
Medan & $y=0.01 x-17.46$ & $\mathrm{y}=0.008 x-12.83$ & $y=0.00 x-4.63$ \\
& $R^{2}=0.01$ & $R^{2}=0.01$ & $R^{2}=0.00$ \\
\hline
\end{tabular}


Lismalini et al: Long-Term Change in Characteristics of Cloud Vertical Structures Over Sumatra
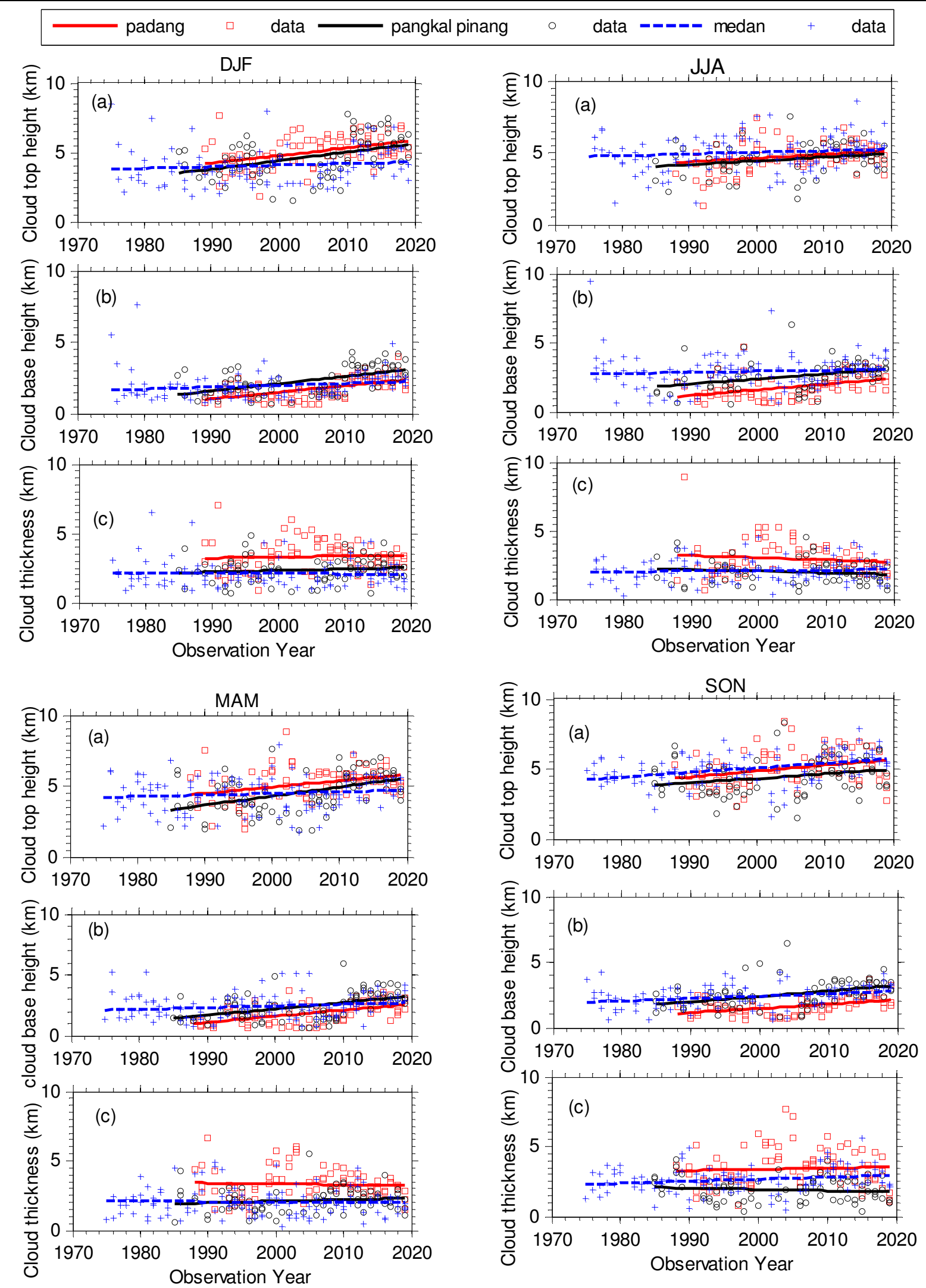

Figure 12. Time series of cloud top height (a), cloud base height (b) and cloud thickness (c) for one-layer cloud during DJF,JJA, MAM and SON periods 
Lismalini et al: Long-Term Change in Characteristics of Cloud Vertical Structures Over Sumatra from

Table 4. Linear regression equation of one-layer cloud for MAM period

\begin{tabular}{llll}
\hline Station name & Cloud top height & Cloud base height & Cloud thickness \\
\hline Padang & $y=0.04 x-83.29$ & $y=0.05 x-98.27$ & $y=-0.00 \times 14.98$ \\
\hline \multirow{3}{*}{ Pangkal Pinang } & $R^{2}=0.11$ & $R^{2}=0.25$ & $R^{2}=0.00$ \\
& $y=0.06 x-124.82$ & $y=0.05 x-103.55$ & $y=0.01 x-21.27$ \\
Medan & $R^{2}=0.21$ & $R^{2}=0.22$ & $R^{2}=0.02$ \\
& $y=0.01 x-18.10$ & $y=0.01 x-24.87$ & $y=-0.00 x 6.76$ \\
& $R^{2}=0.01$ & $R^{2}=0.03$ & $R^{2}=0.00$ \\
\hline
\end{tabular}

Table 5. Linear regression equation of one-layer cloud for SON period

\begin{tabular}{llll}
\hline Station name & Cloud top height & Cloud base height & Cloud thickness \\
\hline Padang & $y=0.04 x-78.43$ & $y=0.03 x-64.06$ & $y=0.01 x-14.37$ \\
\hline \multirow{3}{*}{ Pangkal Pinang } & $R^{2}=0.10$ & $R^{2}=0.21$ & $R^{2}=0.00$ \\
& $y=0.03 x-60.57$ & $y=0.04 x-80.81$ & $y=-0.01 x 20.24$ \\
Medan & $R^{2}=0.06$ & $R^{2}=0.18$ & $R^{2}=0.01$ \\
& $y=0.03 x-61.72$ & $y=0.02 x-34.87$ & $y=0.01 x-26.85$ \\
& $R^{2}=0.15$ & $R^{2}=0.09$ & $R^{2}=0.05$ \\
\hline
\end{tabular}

\section{CONCLUSION}

The vertical structure of clouds in Sumatra shows an increase in CT and CBH over time. Onelayer cloud's appearance is more common than other cloud layers, more than $60 \%$. The dominance of one-layer clouds is consistent with some previous studies in other regions. However, the thickness of one-layer clouds varies from one location to another. The clouds' thickness decreases at Padang station and does not change at Pangkal Pinang and Medan stations. We also found that cloud thickness decreases as the number of cloud layers increase. The thickest cloud is observed in a one-layer cloud. The vertical structure of clouds is influenced by the seasons. Seasonal variations in the vertical cloud structure in Sumatra also indicate an increasing trend in the height of CT and CBH in all-season periods. The increase in cloud height parameters in this study is in line with the increase in Indonesia's surface temperature every year reported by several previous researchers. This study provides additional evidence about the impact of climate change on the vertical structure of clouds.

\section{ACKNOWLEDGEMENT}

The present study was supported by the 2020 Magister Thesis Research Grants from the Ministry of Research, Technology, and Higher Education (Contract no: T/2/UN.16.17/PT.01.03/PTMKebencanaan/2020). Furthermore, thanks to the University of Wyoming for radiosonde data. We would like to thank the three anonymous reviewers for their suggestions and comments.

\section{REFERENCE}

Aldian, E. and Susanto, R.D. (2003). Identification of Three Dominant Rainfall Region Within Indonesia and Their Relationship to Sea Surface Temperature, International Journal of Climatology. 23, 12, 14351452, DOI: https://doi.org/10.1002/joc.950.

Borg, L. A., Holz, R. E. and Turner, D. D. (2011). Investigating Cloud Radar Sensitivity to Optically Thin Cirrus Using Collocated Raman Lidar Observations. Geophysical Research Letters. 38, L05807, DOI: https://doi.org/10.1029/2010GL046365.

Chernykh, I.V., Alduchov, O. A and Eskridge, R. E, (2001). Trends in Low and High Cloud Boundaries and Errors in Height Determination of Cloud Boundary, Bulletin of the American Meteorological Society. 82, 1941-1947, DOI: http://org.doi/10.1175/15200477 (2001) 082<1941

Chepfer H, Bony S, Winker D, Cesana G, Dufresne JL, Minnis P, Stubenrauch CJ, Zeng S, (2010). The GCMOriented CALIPSO Cloud Product (CALIPSO-GOCCP), Journal of Geophysical Research, 115, D00H16, DOI: https://doi.org/10.1029/2009JD012251. 
Lismalini et al: Long-Term Change in Characteristics of Cloud Vertical Structures Over Sumatra

Dai, A. G., T. R. Karl, B. M. Sun, and K. E Trenberth, (2006). Recent trends in cloudiness over the United States: A tale of monitoring inadequacies. Bulletin of the American Meteorological Society, 87, 597-60. DOI: https://doi.org/10.1175/BAMS-87-5.

Dong, X.Q., Xi, B. K. and Minnis, P. (2006). A Climatology of Midlatitude Continental Clouds from the ARM SGP Central Facility. Part II: Cloud Fraction and Surface Radiative Forcing. Journal Climate. 19, 1765-1783, DOI: https://doi.org/10.1175/JCLI3710.1

Eastman, R. and Warren, S.G. (2013). A 39-yr Survey of Cloud Changes from Land Stations Worldwide 19712009: Long-Term Trends, Relation to Aerosols, and Expansion of the Tropical Belt. Journal of Climate. 26, 1286-1303. DOI: https://doi.org/10.1175/JCLI-D-12-0028

Gunawan, E, H (2016). Sky Explorer Handbook. https://kafeastronomi.com/cara membaca citra satelit.html/ [accessed 17 May 2020]. (in Bahasa)

King, M. D., S. Platnick, W. P. Menzel, S. A., et al., (2013). Spatial and temporal distribution of clouds observed by MODIS onboard the Terra and Aqua satellites, IEEE Transactions on Geoscience and Remote Sensing. 51, 3826-3852, DOI: https://doi.org/10.1109/TGRS.2012.2227333

Lazaros, O., Cho, N., and Lee, D. (2017). New Insights about Cloud Vertical Structure from CloudSat and CALIPSO observations, Journal of Geophysical Research: Atmospheres. Sep 16; 122 (17), 9280-9300, DOI: https://doi.org/10.1002/2017JD026629

Lazarus, S. M., Krueger, S. K., and Mace, G. G. (2000). A Cloud Climatology of the Southern Great Plains ARM CART, Journal Climate. 13, 1762-1775, DOI: https://doi.org/10.1175/1520.

Li, Z. Q., Lau, W. K., Ramanathan, V., et al., (2016) . Aerosol and Monsoon Climate Interactions over Asia", Reviews of Geophysics. 5: 866-929, DOI: https://doi.org/10.1002/2015RG000500.

Lismalini and Marzuki, (2020a). Long-term Change in Characteristics of Cloud Vertical Structures in Padang from Radiosonde Observations, Journal of Physics: Conference Series. 1528, 012058, DOI: http://org.doi/10.1088/1742-6596/1528/1/012058

Lismalini, Marzuki, Shafii. M, A. and Yusnaini, H. (2020b). Relationship between Cloud Vertical Structures inferred from Radiosonde Humidity Profiles and Precipitation over Indonesia, Proc. The 3rd International Conference on Research and Learning of Physics ICRLP 2020.

Martucci, G., Milroy, C. and O'Dowd, C. D. (2010). Detection of Cloud-Base Height Using Jenoptik CHM15K and Vaisala CL31 Ceilometers. Journal of Atmospheric and Oceanic Technology. 27, 305-318 DOI: https://doi.org/10.1175/2009JTECHA1326.1.

Marzuki, Hashiguchi, H., Yamamoto, M. K., et al., (2013). Cloud Episode Propagation Over the Indonesian Maritime Continent from 10 years of Infrared Brightness Temperature Observations. Atmospheric Research. 120-121, 268-286, DOI: https://doi.org/10.1016/j.atmosres.2012.09.004.

Marzuki, Vonnisa, M., Rahayu, A. and Hashiguchi, H. (2017). Cloud Statistics over the Indonesian Maritime Continent during the First and the Second CPEA Campaigns, Atmospheric Research. 189, 99-110, DOI: https://doi.org/10.1016/j.atmosres.2017.01.019.

Marzuki, H. Hashiguchi, M. Vonnisa, and Harmadi, (2018a). Seasonal and diurnal variations of vertical profile of precipitation over Indonesian maritime continent. Engineering and Mathematical Topics in Rainfall, T. Hromadka, and P. Rao, Eds., InTech Open, Croatia. DOI: https://doi.org/10.5772/intechopen.74044/

Marzuki, Hashiguchi, H., Vonnisa, M. et al. (2018b). Determination of Intraseasonal Variation of Precipitation Microphysics in the Southern Indian Ocean from Joss-Waldvogel Disdrometer Observation during the CINDY Field Campaign. Advances in Atmospheric Sciences. 35, 1415-1427. DOI: https://doi.org/10.1007/s00376-018-8026-5

Marzuki, Krisna, K., Yusnaini. H., et al, (2021). Diurnal variation of precipitation from the perspectives of precipitation amount, intensity and duration over Sumatra from rain gauge observations, submitted International Journal of Climatology.

Minnis, P., and E. F. Harrison (1998). Diurnal variability of regional cloud and clear-sky radiative parameters derived from GOES data. Part I: Analysis method. Journal of Applied Meteorology and Climatology. 23, 993-1011, DOI: https://doi.org/10.1175/15200450

Naud, C. M., Muller, J.-P., and Clothiaux, E. E, (2003). Comparison be-tween active sensor and radiosonde cloud boundaries over the ARM Southern Great Plains site, Journal of Geophysical Research: Atmospheres.,108,D10203, https://doi.org/10.1029/2002JD002887

Reddy, N.N., Ratnam, M.V.,Basha, G., Ravikiran, V. (2018). Cloud Vertical Structure over A Tropical Station Obtained Using Long-term High-resolution Radiosonde Measurements. Atmospheric Chemistry and Physics. 18, 11709-11727. DOI: https://doi.org/10.5194/acp-18-11709-2018,2018 
Lismalini et al: Long-Term Change in Characteristics of Cloud Vertical Structures Over Sumatra from

Rosenfeld, D. and Ulbrich, C. W. (2003). Cloud microphysical properties, processes, and rainfall estimation opportunities. Radar and Atmospheric Science: A collection of Essays in Honor of David Atlas, Meteorological Monographs. 52, 237-258 DOI: https://doi.org/10.1175/00659401.

Sharma, S., Vaishnav, R., Shukla, M. V., et al., (2016). Evaluation of Cloud Base Height Measurements from Ceilometer CL31 and MODIS Satellite Over Ahmedabad, India, Atmospheric Measurement Techniques. 9. 711- 719. DOI: https://doi.org/10.5194/amt-9-711-2016

Simanungkalit, C.W. (2018), Meteorological Observations Using Radiosonde, E-buletin Stasiun Meteorologi Kualanamu. 3-8 (in Bahasa).

Stephens, G. L., Li, J., Wild, M., et al., (2012). An Update on Earth's Energy Balance in Light of the Latest Global Observations, Nature Geoscience. 5, 691-696, DOI: https://doi.org/10.1038/ngeo1580.

Sugimoto, N., Matsui, I., Shimizu, A., Pinandio, M. and Sugondo, S. (2000). Climatological Characteristics of Cloud Distribution and Planetary Boundary Layer Structure in Jakarta, Indonesia revealed by lidar observation. Geophysical Research Letters. $27 \quad$ (18), 2909-2912, DOI: https://doi.org/10.1029/2000GL011544

Susandi, A (2004). The impact of international greenhouse gas emissions reduction on Indonesia. Report on Earth System Science, Max Planck Institute for Meteorology, Germany.

Wang, J. H. and Rossow, W. B. (1995) Determination of Cloud Vertical Structure from Upper air Observations, Journal of Applied Meteorology. 34, 2243-2258 DOI: https://doi.org/10.1175/1520$0450(1995034<2243$

Wang, J. H. and Rossow, W. B. and Zhang, Y.H., (2000). Cloud Vertical Structure and Its Variations from a 20Yr Global Rawinsonde Dataset, Journal of Climate. 13, 3041-3055, DOI: https://doi.org/10.1175/15200442(2000)013<3041:CVSAIV>2.0.CO;2

Warren, S.G., Hahn, C.J., London, J. et al., (1988). Global Distribution of Total Cloud Cover and Cloud Type Amounts over the Ocean. NCAR Technical NoteTN-317+STR, Boulder, Colorado, 42pp.+170 maps (also DOE/ER-0406), DOI: https://doi.org/10.2172/25415329

Zhang, J. Q., Chen, H. B., Li, Z. Q. et al., (2010). Analysis of Cloud Layer Structure in Shouxian, China Using RS92 Radiosonde Aided by 95 GHz Cloud Radar. Journal Geophysics Research. 115 ,D00K30, DOI: https://doi.org/10.1029/2010JD01.

Zhou, C., Zelinka, M.D. and Klein., S. A. (2016). Impact of decadal cloud variations on the Earth's energy budget Nature Geoscience. 9, 871-874. DOI: https://doi.org/10.1038/NGEO2828. 